Article

\title{
Differences in levelFms-Like Tyrosine Kinase-1 (sFlt-1), soluble Endoglin (s-Eng), and Placental Growth Factor (PIGF) between Early Onset Preeclampsia and Late Onset Preeclampsia
}

\author{
Lita Nafratilova ${ }^{1}$, Yusrawati ${ }^{2}$, Irza Wahid $^{3}$ \\ ${ }^{1}$ Masterof Midwifery Faculty of Medicine, Andalas University, Padang \\ ${ }^{2}$ Obstetry Gynecology Faculty of Medicine, Andalas University, Padang \\ ${ }^{3}$ Subdivision of Medical Hematology \& Oncology Faculty of Medicine, Andalas University, Padang
}

\begin{tabular}{l}
\hline SUBMISSION TRACK \\
\hline Recieved: March 28, 2017 \\
Final Revision: May 03, 2017 \\
Available Online: May 15, 2017 \\
KEYwORDS: \\
\hline sFlt-1, sEng, PIGF, PEAD, PEAL \\
CORRESPONDENCE
\end{tabular}

Phone: 081276733011

E-mail: thalove 84@yahoo.com

\section{ABSTRACT}

Early Onset Preeclampsia (EO-PE) is preeclampsia that develops before 34 weeks 'gestation, caused by intrinsic factors, while Late Onset Preeclampsia (LO-PE) is preeclampsia that develops after 34 weeks' gestation due to extrinsic and maternal factors. There is an increased production of antiangiogenic factors (sFlt-1, sEng and PIGF) contribute to pathophysiology of preeclampsia.This study aims to measure the difference of sFlt-1, sEng, PIGF levels between EO-PE and LO-PE. This was an observational study with cross sectional design conducted at Dr. M. Djamil, TK Hospital. III dr. Reksodiwiryo and Biomedical Laboratory FK Unand Padang from August 2017 to August 2018. The sample of this study were 26 severe preeclampsia women : 13 (EO$\mathrm{PE}$ ) and 13 (LO-PE), selected using consecutive sampling. Levels of sFlt-1, sEng, PIGF were examined using the enzyme-linked immunosorbent assay (ELISA) method. Statistical analysis was performed using unpaired t test and Mann-Whitney Test. Results shown that serum levels of sFlt-1 and sEng in (EO-PE) were 9.51 $\pm 0.71 \mathrm{ng}$ / L, $1.44 \pm 0.06 \mathrm{ng} / \mathrm{mL}, 5.79 \pm 0.42 \mathrm{ng} / \mathrm{mL}$ while in PEAL it was $8,89 \pm 0.78 \mathrm{ng} / \mathrm{mL}, 1.35 \pm 0.14 \mathrm{ng} / \mathrm{mL}$, 
$6.72 \pm 0.76$. There were a significant difference with a value of $\mathrm{p}<0.05$. The conclusion of this study is that the levels of sFlt-1 and sEng are higher in (EO-PE) than(LOPE)and PIGF levels was lower in (EO-PE) compared to (LO-PE).

\section{INTRODUCTION}

Preeclampsia is a life-threatening disease and can occur in any pregnant women. Preeclampsia can be divided into two types based on gestational age ie early onset preeclampsia (EO-PE) and late onset preeclampsia (LO-PE). EO-PE is preeclampsia that develops before 34 weeks 'gestation and is strongly associated with trophoblast invasion and failure of spiral arterial remodeling whereas LO-PE is preeclampsia that develops at or after 34 weeks' gestation and is caused by an increased vulnerability of the maternal blood vessels to inflamation in a normal pregnancy or atherosis in a placenta that initially develops normally (Raymond and Peterson, 2011; Costaet al., 2011). The increased production of antiangiogenic factors: receptor tyrosine kinase dissolved fms-1 (sFlt-1) and dissolved endoglin (s-Eng), and decreased circulating levels of free vascular endothelial growth factors contribute to the pathophysiology of PE PE(Cheng, He \& Fu, 2016)

In developed countries, Preeclampsia (PE) is the biggest cause of maternal and fetal morbidity and mortality, estimated to reach 50,000-60,000 maternal deaths annually. According to WHO (2016), almost all $(99 \%)$ cases of maternal deaths occur in developing countries. The maternal mortality rate in Indonesia is much higher when compared to countries in Southeast Asia (Wibowo et al., 2016).

Looking at the results of the 2015 Intercensal Population Survey (SUPAS), the maternal mortality rate reached 305 / 100,000 live births. In Padang City the maternal mortality rate in 2016 was 120 per 100,000 live births. Both of the data above show an improvement in maternal mortality rate, but are still far from the Millennium Development Goals (MDGs) target, especially referring to the target set by the current SDGs, which is $70 / 100,000$ live births. Judging from the causes of maternal mortality whicha are very variable, maternal mortality cause in Indonesia is still dominated by bleeding (30\%), hypertension in pregnancy (25\%), and infection (12\%). In West Sumatra the maternal mortality rate which is caused by hypertension, preeclampsia and eclampsia reaches $44.8 \%$. Data from the Health Office of the Padang city, the maternal mortality rate during childbirth tends to increase annually until 2016, with total 16 people in 2014,17 people in 2015 and 20 people in 2016. While at the Government Hospital Dr. M. Djamil Padang, the incidence of severe preeclampsia / eclampsia continued to increase, from as high as $20.14 \%$ in 2014 , become $32.5 \%$ in 2015, become $33 \%$ in 2016 and the latest data in 2017 (January-June data), 223 cases of severe preeclampsia was found (Medical Record Dr. M. Djamil Hospital Padang, 2017).

Preeclampsia is known as "The Disease of Theories". A lot of theory about the etiology of Preeclampsia is explained, but the exact cause is still unknown. Evidence shows that main pathophysiology of preeclampsia is the imbalance between the 
role of angiogenic factors and antiangiogenic factors. sFlt-1 is a flt-1 receptor variant for placental growth factors, and vascular endothelial growth factor, an antiangiogenic protein and produced by the placenta which can cause systemic endothelial dysfunction (Lok et al., 2008). Soluble endoglin (sEng) is also an antiangiogenic protein identified from the placenta which inhibits TGF- $\beta 1$ signaling in blood vessels and induces vascular permeability, while PIGF is a proangiogenic factor which is also produced by the placenta, which has weak mitogenic activity and affects vascular premeability, but also has potential role for VEGF action on endothelial cells and vascular permeability (Powe et al., 2011). Conclusions from several studies on antiangiogenic and angiogenic biomarkers by Villa, et al. (2013) and RahmiLaila, et al. (2016) regarding sFlt-1, is that serum levels of sFlt-1 in early onset PE are higher than late onset PE. The results of the study by Akbar, et al., (2017) found that soluble endoglin (sEng) serum levels were significantly higher in early onset PE compared to late onset PE (47.65 \pm 40.17 vs $13.46 \pm 9.48)$, while the mean serum PIGF in the early onset PE group $(53.03 \pm 38.07 \mathrm{pg} /$ $\mathrm{mL})$ was lower than late onset PE (241.80 \pm $192.83 \mathrm{pg} / \mathrm{mL}$ ) with $\mathrm{p}<0.0001$ (Ekapatria, et al., 2012).

The development of PE detection and prediction seems to be more directed to the sFlt-1, sEng and PIGF molecule and the examination of angiogenic (sFlt-1, sEng) and antiangiogenic (PIGF) factors in maternal plasma or serum has been proposed as a parameter that has better and more accurate predictive strength that can help identifying women who has potential developing preeclampsia (Andalas, et al., 2010 ; Sanchez-Aranguren et al., 2014; Phipps et al., 2016; Salan, 2017)
There are still few researches on angiogenic biomarkers which assess the three factors (sFlt-1, sEng and PIGF) which are said to contribute to the pathophysiology of Preeclampsia, so the authors are interested in knowing and conducting research on differences of sFlt-1, s-Eng, PIGF levels in early onset and late onset PE.

\section{METHODS}

This was observational study using cross sectional design. The study was conducted at Dr.M. Djamil Padang, TK Hospital. III Dr. Reksodiwiryo Padang from August 2017 to August 2018. Examination of serum levels of sFlt-1, sEng, PIFG in early onset preeclampsia and late onset preeclampsia at the Laboratory of Molecular Biology, Faculty of Medicine, Andalas University, Padang. The population in this study were all pregnant women with pregnancy $\geq 20-42$ weeks, with a diagnosis of severe preeclampsia. The sample in this study was part of the population that met the inclusion and exclusion criteria of the study, which included the inclusion criteria for pregnant women with gestational age $\geq 20$ 42 weeks diagnosed with severe preeclampsia based on clinical symptoms and laboratory results and willing to be respondents in the study. Exclusion criteria are pregnant women with fetal death in the womb. Based on the calculation of the sample size from the 3 variables, the largest number of samples was taken, totaling 13 people, grouped divided into 13 people with early onset preeclampsia (EO-PE) and 13 people with late onset preeclampsia (LOPE), so that the total sample size in this study was 26 people taken using consecutive sampling technique. Examination of serum levels of sFlt-1, sEng, PIGF was carried out by taking 3 cubic media vein as much as $3 \mathrm{cc}$ 
using $3 \mathrm{ml}$ syringe then centrifuging to obtain \pm 100 micro serum and then examining sFlt-1, sEng, PIGF levels using ELISA method. The levels of sFlt-1 and PIGF levels were analyzed by unpaired t test, the level of analysis using the Mann Whitney Test.

\section{RESULTS}

Characteristics of study subjects and results can be seen in the table below:

Table 1. Characteristics of Study Subjects

\begin{tabular}{|c|c|c|c|c|}
\hline \multirow{4}{*}{ Characteristics } & \multicolumn{4}{|c|}{ Grouping } \\
\hline & \multicolumn{3}{|c|}{ Early Onset Preeclampsia } & Late Onset Preeclampsia \\
\hline & \multicolumn{4}{|c|}{$n=13 n=13$} \\
\hline & Median & Min-Max & Med & Min-Max \\
\hline Age (years) Mean \pm SD & \multicolumn{2}{|c|}{$30.08 \pm 5.78$} & & $3169+623$ \\
\hline Pregnancy Age (Weeks) & \multicolumn{2}{|c|}{$30.92 \pm 1.70$} & \multicolumn{2}{|c|}{$38.62 \pm 2.63$} \\
\hline Parity (Person) & 2 & $1-4$ & 3 & $1-6$ \\
\hline BP Systolic (mmHg) & 180 & $150-235$ & 162 & $160-200$ \\
\hline BP Diastolic $(\mathrm{mmHg})$ & 120 & $100-160$ & 110 & $100-140$ \\
\hline History of preeclampsia & $f$ & $\%$ & $f$ & $\%$ \\
\hline There is a history of & 4 & 30.77 & 2 & 15.38 \\
\hline no history & 9 & 69.23 & 11 & 84.62 \\
\hline Hypertension & $\mathrm{f}$ & $\%$ & $\mathrm{f}$ & $\%$ \\
\hline There is a history of & 5 & 38.46 & 3 & 23.08 \\
\hline no history & 8 & 61.54 & 10 & 76.92 \\
\hline
\end{tabular}

Based on table 1. it can be concluded that the mean age of LO-PE (31.69 \pm 6.23 years) is higher than the mean age of EO-PE $(30.08 \pm 5.78$ years $)$. Mean gestational age at LO-PE (38.62 \pm 2.62 weeks) while mean gestational age at EO-PE $(30.92 \pm 1.70$ weeks). The parity of preeclampsia is morelikely in LO-PE. Median value for systolic and diastolic BP is high on EO-PE compared to LO-PE. History of preeclampsia and hypertension history is more likely in EO-PE than LO-PE. The results of the three variables can be seen in the table below :

Table 2. Distribution oflevels of solubleFms-Like Tyrosine Kinase-1 (sFlt-1) between EO-PE and LO-PE

\begin{tabular}{lcc}
\hline Group & Level Soluble Fms-Like Tyrosine Kinase-1(sFlt-1) (ng \\
& $\mathrm{n}$ & Mean \pm SD \\
\hline Early onset preeclampsia (EO-PE) & 13 & $9.51 \pm 0.71$ \\
Late onset preeclampsia (LO-PE) & 13 & $8.89 \pm 0.78$ \\
\hline
\end{tabular}

In table 2. It can be seen that the distribution oflevels Fms-like solubleTyrosine kinase-1 (sFlt-1)
inEO-PE is $9.51 \pm 0.71 \mathrm{ng} / \mathrm{mL}$ higher than LO-PE $8.89 \pm 0.78 \mathrm{ng} / \mathrm{mL}$. 
Table 3. Distribution oflevels Endoglin soluble (sEng) between EO-PE and LOPEEndoglin

\begin{tabular}{|c|c|c|}
\hline \multirow[t]{2}{*}{ Group } & \multicolumn{2}{|c|}{ soluble $(\mathrm{sEng})(\mathrm{ng} / \mathrm{mL})$} \\
\hline & $\mathrm{n}$ & Median Min-Max \\
\hline Early onset preeclampsia (EO-PE) & 13 & $28.3120 .8-35.06$ \\
\hline Late onset preeclampsia (LO-PE) & 13 & $26.859 .98-28.58$ \\
\hline
\end{tabular}

In table 3. it can be seen that the distribution PEthat is $28.31(20.8-35) \mathrm{ng} / \mathrm{mL}$ higher oflevels Endoglin soluble ( $\mathrm{sEng}$ ) in EO- than LO-PE 26.85 (9.98-28.58) $\mathrm{ng} / \mathrm{mL}$.

Table 4. Distribution of Placental Growth Factor (PIGF) levels between EO-PE and LO-PE in

\begin{tabular}{lcc}
\hline Group & \multicolumn{2}{c}{ Placental Growth Factor (PIGF) (ng / mL) } \\
\cline { 2 - 3 } & $\mathrm{n}$ & Mean \pm SD \\
\hline $\begin{array}{l}\text { Early onset preeclampsia (EO- } \\
\text { PE) }\end{array}$ & 13 & $5.79 \pm 0.42$ \\
Late onset preeclampsia (LO- & 13 & $6.72 \pm 0.76$ \\
PE) ) & & \\
\hline
\end{tabular}

In table 4. it can be seen that the (PIGF) levels in EO-PE is $5.79 \pm 0.42 \mathrm{ng} /$ distribution of Placental Growth Factor mL lower than LO-PE 6.72 $\pm 0.76 \mathrm{ng} / \mathrm{mL}$.

Table 5. Differences inlevels of solubleFms-Like Tyrosine Kinase-1 (sFlt-1), soluble Endoglin (sEng), Placental Growth Factor (PIGF)

\begin{tabular}{ccccc}
\hline \multirow{2}{*}{ Variable } & \multicolumn{2}{c}{ EarlyOnset Preeclampsia } & \multicolumn{2}{c}{ Late onset preeclampsia } \\
\cline { 2 - 4 } & Mean \pm SD & $\begin{array}{c}\text { Median (Min- } \\
\text { Max })\end{array}$ & Mean \pm SD Median (Min-Max) & \\
\hline sFlt-1 $(\mathrm{ng} / \mathrm{mL})$ & $9.51 \pm 0.71$ & & $8.89 \pm 0.78$ & 0.045 \\
\hline sEng $(\mathrm{ng} / \mathrm{mL})$ & & $\begin{array}{c}28,31 \\
(20,8-35,06)\end{array}$ & $\begin{array}{c}26,85 \\
(9,98-28,58)\end{array}$ & 0,048 \\
\hline PIGF $(\mathrm{ng} / \mathrm{mL})$ & $5.79 \pm 0.42$ & & $6.72 \pm 0.76$ & 0.001 \\
\hline
\end{tabular}

In table 5. Levels of sFlt -1 andsEng higher in EO-PE compared to LO-PE, PIGF levels in EO-PE are lower than LO-PE. The results of statistical tests also showed that there were significant differences, $\mathrm{p}<0.05$.

\section{DISCUSSION}

Differences exist between soluble levels of Fms-Like Tyrosine Kinase-1 (sFlt1), soluble Endoglin(sEng) and Placenta Growth Factor (PIGF) between Early Awarenes Preeclampsia (EO-PE) and Slow Onset Preeclampsia (LO-PE).
Based on the results of the study, it was found that the soluble Fms-Like Tyrosine Kinase-1 (sFlt-1) and soluble Endoglin(sEng) was higher in EO-PE (9.51 \pm $0.71 \mathrm{ng} / \mathrm{mL}, 28.31 \mathrm{ng} / \mathrm{mL}$ ) compared with in LO-PE $(8.89 \pm 0.78 \mathrm{ng} / \mathrm{mL}, 26.85 \mathrm{ng} /$ $\mathrm{mL})$. Whilethe mean rate of Placental Growth Factor (PIGF) in the EO-PE group was lower than that of the LO-PE group, $5.79 \pm 0.42 \mathrm{ng} / \mathrm{mL}$ and $6.72 \pm 0.76 \mathrm{ng} / \mathrm{mL}$ respectively. These differences were significant with a value of $\mathrm{p}<0.05$. The increased soluble level of Fms-Like tyrosine 
kinase-1, soluble Endoglin(sEng) accompanied by decreased levels of Placenta Growth Factor (PIGF) suggests an imbalance between antiangiogenic and angiogenic levels that may result in endothelial dysfunction. The occurrence of EO-PE and LO-PE is due to malperfusion and placental dysfunction, so maternal factors can be said to contribute to increasing the incidence of all preeclampsia, both EO-PE and LO-PE. (Cathrine-Anne and Readman, 2018)

\section{CONCLUSION}

There was a significant difference between the levels of soluble fms-like tyrosine kinase-1 (sFlt-1) and soluble Endoglin (sEng) in each group which were higher in EO-PE than in LO-PE while Placental Growth Factor (PIGF) was lower in EO-PE compared to LO-PE.

There is a significant difference that fms-like tyrosine kinase-1 (sFlt-1) and soluble endoglin (sEng) levels in Early Onset Preeclampsia (EO-PE) are higher compared to Late Onset Preeclampsia (LO-PE) whereas the Placental Growth Factor (PIGF) lower in Early Onset Preeclampsia (EO-PE) compared to Late Onset Preeclampsia (LO$\mathrm{PE})$.

\section{REFERENCES}

Akbar, M, A, Herdiyantini, M, Aditiawarman. Perbandingan kadar soluble Endoglin (sEng) serum pada penderita Preeklamsia Tipe dini, Tipe lambat dan ibu hamil normal. Majalah Obsetri \& Genekologi, Volume 25 No 1, pp. 10-15.2017.

Andalas, M. Harapan. Antagonis soluble tms-Like Tyrosine Kinase 1 (sFlt-1) dan soluble endogline (sEng) pada preeklamsia. JIK, Volume 1, pp. 1-9. 2010.

Berthold .H. Placental Origins of Preeclampsia. In :Challenging the Current Hypothesis. American Heart Association. 2008.

Cheng M, He P, Fu J. "The relationship between circulating tissue transglutaminase, soluble fms-like tyrosine kinase-1, soluble endoglin and vascular endothelial growth factor in pre-eclampsia. Journal of human hypertension . 30, 788-793. 2016.

Costa, FS. Murthi, P. Keogh, R. Woodrow, N. Early Screening for Preeclamsia. MelbourneAustralia : Rev Bras Ginecol Obstet. 2011 ; 33 (11) : 367-75. 2011.

Dinas Kesehatan Kota Padang. Profil Kesehatan Kota Padang tahun 2016. Padang : Dinas Kesehatan Kota Padang. 2016.

Ekapatria, C., Sabarudin, U. \& Sasotya, S. Placental Growth Factor Level in Lower in earlyOnset Preeclamsia, while Tumor Necrosis factor Alpha Level Does not Show any Difference between Early and late Onset Preeclampsia. Maj Obstet Ginekol Indonesia, Volume 36 No 4, pp. 36-4 : 181-4. 2012.

Gulec UK, Ozgunen FT, Buyukkurt S, Guzel AB, Urunsak IF, DemirSC,et al. Comparison of clinical and laboratory findings in early and late onset preeclampsia.TheJournalof Maternal-Fetal\& Neonatal Medicine. 26-(12):1228-33. 2013. 
Hirashima C, Ahkuchi A, Matsubara S, Suzuki H, Takahashi K, Usui R, Suzuki M. “ Alteration of serum soluble endoglin levels after the onset of preeclampsia is more pronounced in women with early-onset. Hipertens Res. Vol 31, No 8. 2008

Lok, CA ; An, Boing ; IL Sargent, et al.Circulating Platelet-derived and placental-derived microparticle expose flt-1 in preeclampsia. Reproduction Scince, Volume 15, pp. 10021010. 2008.

Mbah AK, Kornosky JL, Kristensen S, Agust EM, Alo AP, Marty PJ, et al. Super Obesity and Risk for early and late preeclamsia. BJOG. 117 : 997-1004. 2010.

Perales A, Delgado JL, Calle M. De la, Hernandez Garcia, Escudero A.I, Campillos J.M, et al. sFlt-1/PIGF for prediction of early-onset pre-eclampsia : Steps (Study of early preeclampsia in Spain). Ultrasound Obstet Gynecol. 50 : 373-382. 2017.

Phipps, E.,Prasanna, D., Brima., W. \& Jim, B., Preeclampsia : Updates in Pathogenesis, Definitions, and Guidelines, Clin J Am Soc Nephrol, Volume 11, pp. 1102-1113.2016.

Powe CE, Levine RJ, Karumanchi SA. (2011). "Preeclampsia, A Disease of The Maternal Endothelium: The Role of Anti-Angiogenic Factors and Implications for Later Cardiovascular Disease. Howard Hughes Medical Institute. 21:123 (24). 2011.

Rahmi, L., Herman, B \& Yusrawati. Perbedaan Rerata Kadar Soluble fms-like Tyrosine Kinase-1 (sFlt-1) Serum pada penderita Early Onset,Late Onset Preeklamsia Berat/Eklamsia dan Kehamilan Normal. Jurnal Kesehatan Andalas, p.5 (1). 2016.

Raymon D, Peterson E. "A Critical Review of Early-Onset and Late-Onset Preeclampsia. Obstetry Gynecol.66(8): 497-506. 2011.

Reslan OM, Khalil RA. Molecular And Vascular Targets in The Pathogenesis and Management of The Hypertension Associated With Preeclampsia. Cardiovascular Hematol Agents Med Chem. 8(4): 204-226. 2010.

Rezi Elma, Yusrawati, Iryani Detty. Perbedaankadar Soluble endoglinPadaPreeklamsiAwitanDini (PEAD) denganPreeklamsiawitanlambat (PEAL).Jurnal Kesehatan Andalas. 2017.

RSUP Dr.M.Jamil. Data Medical Record RSUP Dr. M. Djamil Padang. 2017

Salan, Y. Biomarker Terkini Dalam Usaha Memperdiksi Preeklamsia. Berkala Kedokteran, Volume 13, pp. 119-128.2017

Sanchez-Aranguren LC, Prada CE., Riano-Medina CE, Lopez M. "Endothelial Dysfunction and Preeclampsia" : Role Of Oxidative Stress. Physiol : 5:372. 2014.

Sinuraya Rano K, Nisa Hidayatun, Lokajaya Trifena, Puri Tri NS. Biomarker PIGF/sFlt-1 sebagai Pendeteksi dini Preeklamsia. Jurnal Farmasi Klinik Indonesia. Vol.6 No. 2, hlm 123-134. 2017.

Soto, Eleazar ; Romeo, Roberto ; Kusnovic, Pedro, Juan ; Giovanna ; Hussein, Youssef : yeo, Lami : Hassan, S; Kim, Jai, Choy; Chaiworapongsa, Yinnakorn. Late-Onset Preeclamsia is Associated With An Imbalance of Angiogenic and Anti-Angiogenic 
Factror in Patiens With and Without Placental Lesions Consistent With Maternal Underperfusion. J. Matern Fetal Neonatal Med, pp. 498-507. 2012.

SUPAS. Profil Penduduk Indonesia Hasil SUPAS 2015, Jakarta : Badan Pusat Statistik. 2015

Villa, PM. Hamalainer, E. Maki, A. Raikkonen, K. Pesonen, A. Taipale, P. et al. Vasoactive agents for the prediction of early and late-onset preeclamsia in a high-risk cohort. $B M C$ Pregnancy and Childbirth. Volume 13 : 110. 2013.

Vinayagam V, Bobby Z, Habeebullah S, Latha CH, Bharadwaj S.Maternal and cord bloodplasma sEngdanTGF- $\beta 1$ in patients with hypertensive disorders of pregnancy: A pilot study in a south indian population.Journal of clinical and diagnostic research :vol 11(3): QC32-QC3. 2017.

WHO. Maternal Mortaliti: www.who.int/mwdiacentre/factsheets/fs348/e.2016

Wikstrom AK,Larsson, A. Eriksson, UJ. Nash, P. Norden-Lindeberg, S. Olovsson, M. Placental growth factor and soluble fms-like tyrosine kinase-1 in early onset and late onset preeclamsia. Obstetri and Gynecology. June : 109 (6) : 1368-74. 2007

Wibowo, Noroyono; Irwinda, Rima; Frisdiantiny, Edwina ; Karkata, Kornes ; Mose, c et al., [Online] Available at: or.id/publish/download/pnpk-dan-ppk [Diakses 611 2017].

Yusrawati. Perantakikdiastolikarteriuterinasebagaifaktorrisikodanperbedaanresistensi insulin, adma, hscrpdanadiponektinantarapreeklamsiaawitandinidanpreeklamsiaawitanlambat. Masters thesis, universitasandalas. 2015 